| Dossiê: Impactos e Repercussões Socioambientais de Empreendimentos na Pan-Amazônia| DOI: http://dx.doi.org/10.18764/2446-6549.202006

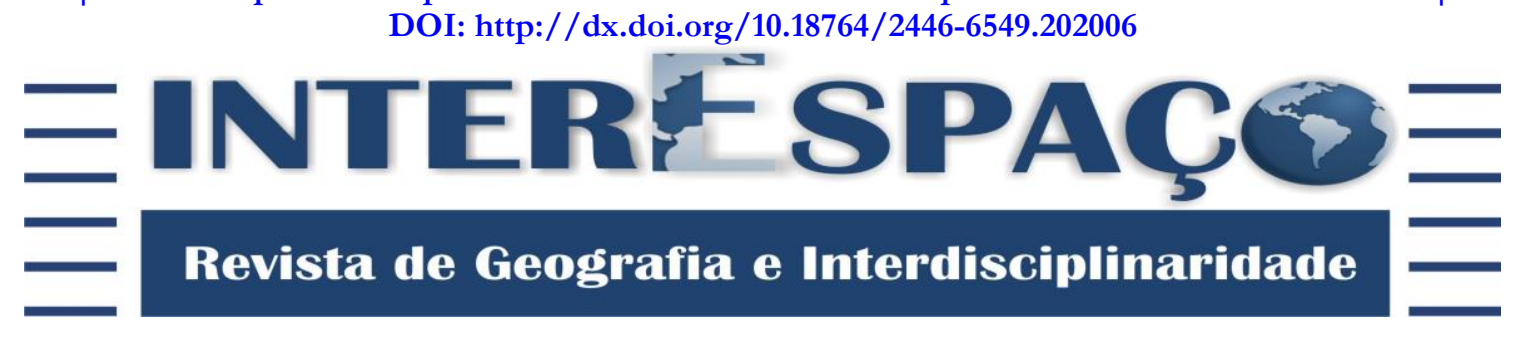

\title{
EXPANSÃO DA SILVICULTURA DO EUCALIPTO E TRANSFORMAÇÕES NO USO DA TERRA EM MUNICÍPIOS DO OESTE MARANHENSE
}

\section{EXPANSION OF EUCALYPTUS FORESTRY AND TRANSFORMATIONS IN LAND USE IN MUNICIPALITIES IN WEST MARANHENSE}

\section{EXPANSIÓN DE EUCALIPTO FORESTAL Y TRANSFORMACIONES EN EL USO DE LA TIERRA EN MUNICIPIOS EN OESTE MARANHENSE}

\begin{abstract}
Allison Bezerra Oliveira
Doutor em Geografia pela Universidade Federal de Pernambuco - UFPE. Professor do Curso de Geografia da Universidade Estadual da Região Tocantina do Maranhão - UEMASUL. Membro do Grupo de Pesquisas Socioeconômicas do MA - GPS. allisonbzr@gmail.com / http://orcid.org/0000-0003-0320-5661
\end{abstract}

\section{Diego Armando Souza Paz}

Economista. Bolsista de Apoio Técnico Institucional e Graduando no Curso de Geografia da Universidade Estadual da Região Tocantina do Maranhão - UEMASUL. Membro do Grupo de Pesquisas Socioeconômicas do MA - GPS.

d.armando146@hotmail.com / http://orcid.org/0000-0001-7360-6554

\section{Keilha Correia da Silveira}

Doutora em Geografia pela Universidade Federal de Pernambuco - UFPE. Professora do Curso de Geografia da Universidade Estadual da Região Tocantina do Maranhão - UEMASUL. Membro do Grupo de Pesquisas Socioeconômicas do MA - GPS. silveira.kc@gmail.com / http://orcid.org/0000-0002-2908-6739

Recebido para avaliação em 21/05/2020; Aceito para publicação em 10/11/2020.

\section{RESUMO}

O presente trabalho tem por objetivo compreender transformações recentes no uso da terra frente o avanço da silvicultura do eucalipto em quatro municípios do oeste maranhense: Imperatriz, Cidelândia, São Pedro d'Água Branca e Vila Nova dos Martírios. E como tal, discute o processo de inserção desta cultura no estado e algumas das transformações decorrentes deste avanço. o trabalho utiliza dados primários, fruto de pesquisas de campo que objetivaram a construção de acervo fotográfico, e realização de entrevistas não estruturadas com representantes de moradores, funcionários de fazendas e produtores rurais das áreas sob avanço do eucalipto nos municípios em destaque. Os dados secundários, sistematizados em mapas, gráficos e tabelas, são resultantes de informações colhidas no Instituto Nacional de Colonização e Reforma Agrária (INCRA), Instituto Maranhense de Estudos Socioeconômicos e Cartográficos (IMESC), o Instituto Brasileiro de Geografia e Estatística (IBGE) e os relatórios de produção da própria Suzano Papel e Celulose.

Palavras-chave: Uso da Terra; Silvicultura do Eucalipto; Oeste Maranhense.

\section{ABSTRACT}

The present work aims to understand recent transformations in the use of land in the face of the advance of Eucalyptus forestry in four municipalities in the west of Maranhão: Imperatriz, 
|Expansão da silvicultura do eucalipto e transformações no uso da terra em municípios do Oeste Maranhense |

|Allison Bezerra Oliveira | Diego Armando Souza Paz | Keilha Correia da Silveira |

Cidelândia, São Pedro d'Água Branca and Vila Nova dos Martírios. And as such, it discusses the process of inserting this culture into the state and some of the transformations arising from this advancement. The work uses primary data, fruit of field research that aimed at building photographic collections, and conducting unstructured interviews with residents' representatives, employees of farms and rural producers of the areas under Eucalyptus advance in the municipalities highlighted. Secondary data, systematized in maps, graphs and tables, are the result of information collected at the National Institute of Colonization and Agrarian Reform (INCRA), Maranhense Institute of Socioeconomic and Cartographic Studies (IMESC), and the Brazilian Institute of Geography and Statistics (IBGE).

Keywords: Land Use; Eucalyptus Forestry; West Maranhense.

\section{RESUMEN}

El presente trabajo tiene por objeto comprender transformaciones recientes en el uso de la tierra frente al avance de la silvicultura del eucalipto en cuatro municipios del oeste maranhense: Emperatriz, Cidelandia, São Pedro d'Água Branca y Vila Nova dos Martirios. Y como tal, discute el proceso de inserción de esta cultura en el estado y algunas de las transformaciones resultantes de este avance. El trabajo utiliza datos primarios, fruto de investigaciones de campo que objetivaron la construcción de acervo fotográfico, y realización de entrevistas no estructuradas con representantes de residentes, funcionarios de granjas y productores rurales de las áreas bajo avance del eucalipto en los municipios destacados. Los datos secundarios, sistematizados en mapas, gráficos y tablas, son resultantes de informaciones recogidas en el Instituto Nacional de Colonización y Reforma Agraria (INCRA), Instituto Maranhense de Estudios Socioeconómicos y Cartográficos (IMESC), el Instituto Brasileño de Geografía y Estadística (IBGE) y los informes de producción de la propia Suzano Papel y Celulosa.

Palabras clave: Uso del Suelo; Eucalipto Forestal; Oeste Maranhense.

\section{INTRODUÇÃO}

Após a década de 1970, grandes empresas beneficiadas por incentivos fiscais da Superintendência do Desenvolvimento da Amazônia (Sudam) começaram a ocupar vastas extensões de territórios amazônicos, assim expandindo a fronteira agrícola e florestal. Esse processo, segundo Oliveira (2019), foi desencadeado por ação estatal que, aliada ao grande capital, converteu a Amazônia em fronteira do capital natural em nível global, num cenário de atração de grandes empreendimentos, grilagem de terras e conflitos agrários.

O Estado brasileiro, por meio de suas políticas macroeconômicas, é, portanto, historicamente, o principal agente incentivador da expansão da fronteira agrícola brasileira, principalmente em direção à Amazônia Legal. A criação da Amazônia Legal, em 1953, tornou-se um marco da gestão e centralização do poder estatal sobre o território brasileiro. Sob o argumento de proteção estratégica desse domínio, o grande capital, em especial o estrangeiro, foi inserido de forma intensa em toda uma região, produzindo uma aceleração da mercantilização natural e a geração dos mais diversos tipos de impactos e conflitos.

Nesse quadro analítico, a Amazônia Legal serviu para o avanço do principal modelo de crescimento econômico adotado pelo Brasil, o modelo de fronteira agrícola. A expansão 
| Expansão da silvicultura do eucalipto e transformações no uso da terra em municípios do Oeste Maranhense |

|Allison Bezerra Oliveira | Diego Armando Souza Paz | Keilha Correia da Silveira |

da fronteira brasileira não só promoveu a devastação de áreas naturais, como acelerou a concentração de terra, de renda e promoveu a expropriação de diversos grupos sociais existentes na região, contribuindo, assim, para o enriquecimento de grandes empresas e oligarquias e para a vulnerabilidade dos mais pobres.

No contexto de ampliação de fronteiras no Brasil, em especial a do eucalipto iniciada na década de 1980 com o Projeto Grande Carajás, no Pará, e o complexo siderúrgico produtor de ferro-gusa, de Açailândia, Maranhão - está o início da implantação da unidade fabril da Suzano Papel e Celulose no município de Imperatriz, região amazônica maranhense, em 2008. Tal unidade industrial proporcionou não só a manutenção da fronteira agrícola do eucalipto na região, como tem promovido a intensificação de seu avanço.

Em consequência, a reestruturação regional produzida tem ocasionado modificações significativas na matriz produtiva, nas relações de trabalho (em especial o agrário) e nas formas de uso e apropriação dos territórios. Principalmente aqueles direcionados para a produção de subsistência alimentar, seja por assentados ou pequenos produtores.

Nesse contexto, o presente trabalho tem por objetivo compreender transformações recentes no uso da terra frente o avanço da silvicultura do eucalipto em quatro municípios do oeste maranhense: Imperatriz, Cidelândia, São Pedro d’Água Branca e Vila Nova dos Martírios. E como tal, discute o processo de inserção desta cultura no estado e algumas das transformações decorrentes deste avanço.

A escolha destes municípios se dá frente a posição geográfica no curso do Rio Tocantins, a localização na Amazônia maranhense, de estarem em região de fronteira com os estados do Tocantins e Pará, além do fato de que é na cidade de Imperatriz que está localizada a unidade fabril da Suzano.

Metodologicamente, o trabalho utiliza dados primários, fruto de pesquisas de campo que objetivaram a construção de acervo fotográfico, e realização de entrevistas não estruturadas com representantes de moradores, funcionários de fazendas e produtores rurais das áreas sob avanço do eucalipto nos municípios em destaque. Os dados secundários, sistematizados em mapas, gráficos e tabelas, são resultantes de informações colhidas no Instituto Nacional de Colonização e Reforma Agrária (INCRA), Instituto Maranhense de Estudos Socioeconômicos e Cartográficos (IMESC), o Instituto Brasileiro de Geografia e Estatística (IBGE) e os relatórios de produção da própria Suzano Papel e Celulose. 
|Expansão da silvicultura do eucalipto e transformações no uso da terra em municípios do Oeste Maranhense |

|Allison Bezerra Oliveira | Diego Armando Souza Paz | Keilha Correia da Silveira |

Além desta introdução e das considerações finais, o presente artigo está estruturado da seguinte forma: inicialmente discute-se a ocupação e uso do território no Maranhão e suas relações de trabalho; em seguida aborda-se o processo histórico de implementação da silvicultura de eucalipto no Brasil e no Maranhão, considerando o avanço dessa atividade como cadeia produtiva no estado e no país. Por fim, analisa-se a expansão da silvicultura do oeste do estado, e algumas transformações observadas em comunidades rurais nos municípios estudados.

\section{OCUPAÇÃO E USO DO TERRITÓRIO NA AMAZÔNIA MARANHENSE}

A atual porção amazônica maranhense abrange uma área equivalente a $80 \%$ da superfície territorial do estado, compreendendo 180 dos seus 217 municípios, distribuídos em cinco mesorregiões e 21 microrregiões. Logo, deve-se considerar a especificidade geográfica da integração do estado do Maranhão na composição da Amazônia Legal (MESQUITA et al., 2015).

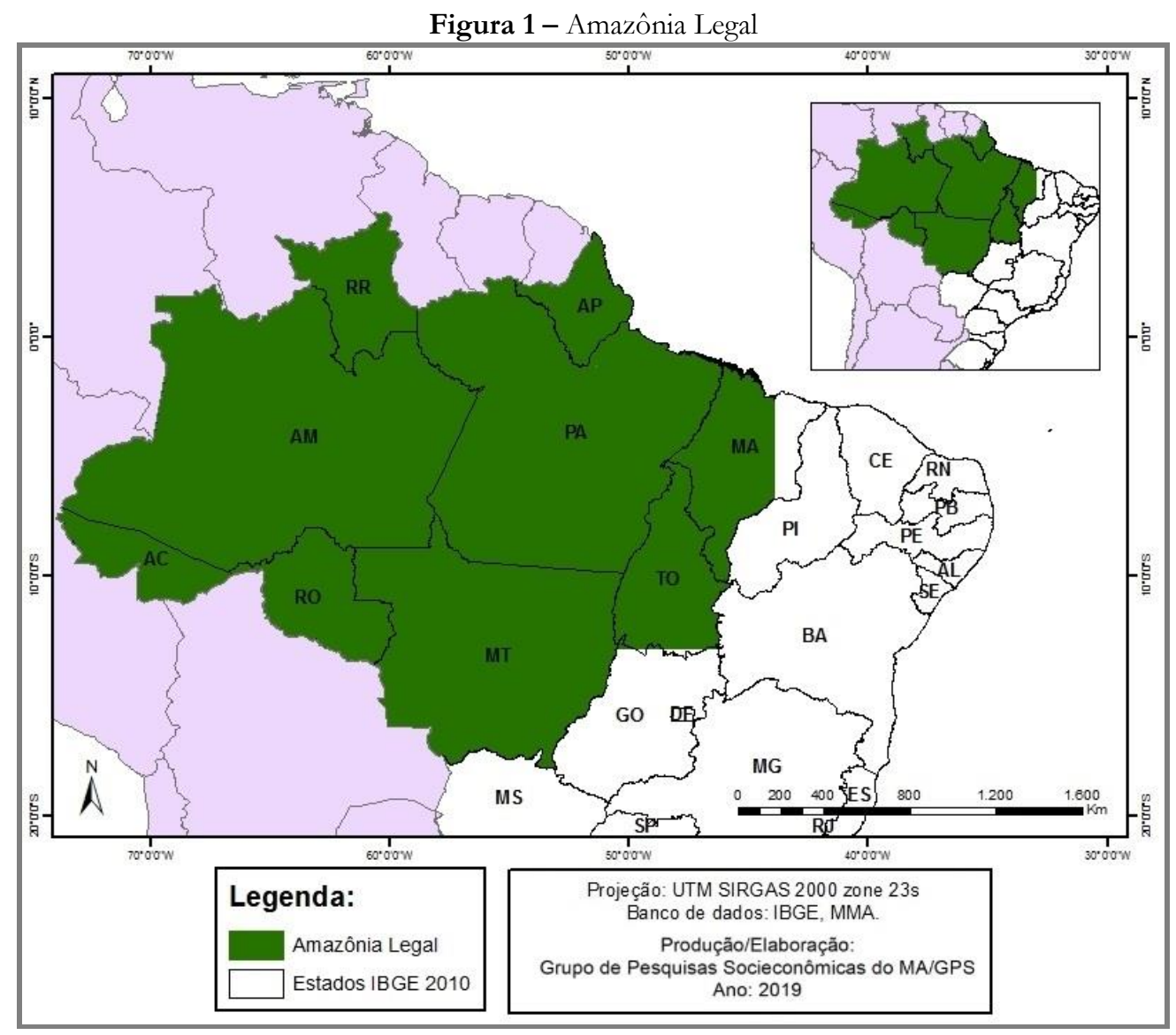

Fonte: Oliveira (2019). 
| Expansão da silvicultura do eucalipto e transformações no uso da terra em municípios do Oeste Maranhense |

|Allison Bezerra Oliveira | Diego Armando Souza Paz | Keilha Correia da Silveira |

A própria história da formação territorial do Maranhão se confunde em muitos momentos com a da região amazônica, por isso a importância de se considerar o contexto de criação da Amazônia Legal (Figura 1) como elemento fundamental na constituição socioeconômica atual do Maranhão. Soma-se a isso o fato de que a constituição de tal demarcação política desencadeou processos econômicos que promoveram significativas transformações locais (OLIVEIRA, 2019).

A ocupação da Amazônia maranhense teve início no fim do século XVI, e até o século XVII a economia era pautada essencialmente em atividades voltadas para o extrativismo de especiarias. Mais tarde foram introduzidas as produções de açúcar, algodão e arroz, que tiveram papel primordial na ocupação da região e na ampliação das fronteiras brasileiras. Dessa forma, a ocupação e o uso do território da Amazônia maranhense se resumiram, no século XVII, ao extrativismo e ao comércio de produtos primários, assim penetrando florestas e rios para a coleta de matéria-prima. Ainda no fim do século XVII, mais precisamente em 1682, foi criada a Companhia de Comércio do Maranhão, com o objetivo de fornecer crédito para a exportação de algodão e escravos para produtores da região. Contudo, uma série de reclamações ocasionaram revoltas que culminaram com a extinção dessa companhia (MESQUITA et al., 2015).

O século XVIII foi marcado pela expansão da pecuária, que ocupou boa parte do sul do estado, sendo um fator importante para o processo de ocupação de terras devolutas e uso do território da Amazônia maranhense. Também marcou esse século o crescimento na produção de arroz, algodão e cana-de-açúcar, com o uso de trabalho escravo africano pela então Companhia Geral de Comércio do Grão-Pará e Maranhão, criada em 1755 (FERREIRA, 2008). Essa companhia foi fundamental para políticas de estímulo à ocupação, comercialização e produção na Amazônia maranhense, no entanto o projeto foi extinto em 1778 (ARCANGELI, 1987).

Mesmo com a extinção da Companhia, a produção de algodão no Maranhão se destacou no início do século XIX, contudo entrou em decadência por conta de alguns fatores como descapitalização dos proprietários rurais e fim do tráfico internacional de escravos em 1850. Com a decadência do algodão, o açúcar e o arroz se tornaram os mais importantes produtos de exportação da província do Maranhão (MESQUITA et al., 2015). Vale destacar, nesse mesmo século, dois marcos importantes: a Lei de Terras, de 1850, que mudou de forma significativa o processo de apropriação de terras; e a abolição da escravatura, em 1888, que mudou consideravelmente as relações de trabalho na região (VIVEIROS, 1954). 
| Expansão da silvicultura do eucalipto e transformações no uso da terra em municípios do Oeste Maranhense |

|Allison Bezerra Oliveira | Diego Armando Souza Paz | Keilha Correia da Silveira |

Ainda referente aos ciclos econômicos do Maranhão, de acordo com Oliveira, Silva e Leal (2019), tem-se, ainda, no ciclo da borracha uma importante contribuição aos processos migratórios da região amazônica do estado, ressaltando as frentes de expansão da estrutura agrária na região. Pode-se considerar que a decadência do primeiro ciclo da borracha (entre 1879 e 1912) promoveu a partir de 1920 o agravamento das correntes migratórias. Nesse sentido, Oliveira et al. (2008) afirmam que a partir de então, por conta do grande número de imigrantes e da vastidão de terras devolutas, surge a figura do posseiro, o indivíduo que ocupa um lote de terras sem títulos de propriedade, dessa forma, desequilibrando a relação camponês e proprietário.

A grilagem de terras foi um fator preponderante para a concentração de terras na Amazônia maranhense. A partir da década 1940, esse processo, juntamente com o açambarcamento ilegal de terra, intensificou-se por conta da pecuária e de grandes projetos agropecuários (ARCANGELI, 1987). Na segunda metade do século XX, foi criado o Projeto de Povoamento do Maranhão (PPM), cujo objetivo era viabilizar a integração e ampliação da fronteira agrícola do Brasil. Também foi determinante para o aumento da concentração de terras (FERREIRA, 2008).

Vieira Filho (2016) afirma que após a década de 1970 grandes empresas beneficiadas por incentivos do Estado começaram a ocupar a Amazônia Legal, assim expandindo a fronteira agrícola que chegou até o Maranhão. Essa expansão vem acarretando uma série de impactos proveniente da exploração econômica do território, tais como: êxodo rural, expropriação de recursos, grilagem de terras, conflitos e mudanças nas relações de trabalho (OLIVEIRA, 2019).

Acerca da Amazônia maranhense, Bolfe et al. (2016, p. 39) afirmam que “a região sul-maranhense, por causa da produção de soja, transformou sua estrutura agrária tradicional de subsistência em agricultura tecnificada". Assim, como já dito, essa especialização produtiva vem ocasionar transformações tanto no modo de exploração da terra como nas relações de trabalhos existentes, provocando impactos já mencionados.

O processo de industrialização do Maranhão se intensificou de fato após a década de 1980, com a chegada de grandes projetos, como a Alumar e o Projeto Grande Carajás no estado do Pará, mas com forte relação econômica com o Maranhão, entre outros aspectos, da construção de um grande corredor de exportação de minérios na Amazônia Legal. Além de incentivos fiscais, foram cedidos à Alumar - a preço simbólico - 10 mil hectares de terra onde viviam cerca de 5 mil famílias que foram retiradas do local (ROLIM FILHO, 2016). 
| Expansão da silvicultura do eucalipto e transformações no uso da terra em municípios do Oeste Maranhense |

|Allison Bezerra Oliveira | Diego Armando Souza Paz | Keilha Correia da Silveira |

Nessa perspectiva, para atender à demanda energética das guseiras que surgiram com a Estrada de Ferro Carajás, além das matas nativas houve a necessidade do reflorestamento de áreas de eucalipto. Contudo, em 1992 foi instalada em Imperatriz a empresa Celmar, que mudou a realidade do eucalipto com o objetivo de cultivar essas florestas para produção de celulose e papel. No entanto, esse empreendimento fracassou, e em 2001 o destino da floresta de eucalipto passou novamente a ser produzir carvão vegetal para abastecimento das usinas siderúrgicas no município de Açailândia. Posteriormente, as florestas de eucalipto foram vendidas para a Suzano Papel e Celulose, que em 2008 instalou uma fábrica em Imperatriz (OLIVEIRA, 2019).

$\mathrm{Na}$ Amazônia maranhense, houve, portanto, um intenso processo de desterritorialização por conta desses empreendimentos, sendo mais frequente a retirada de nativos do seu território original, com indenizações ou remanejamento dessas populações para áreas distantes, guardando alguma semelhança com o que ocorria no período colonial.

Outra face desse processo é a limpeza ou cercamento de áreas decorrentes de grilagens e compra de grandes extensões de terras públicas e privadas. No caso de várias fazendas de silvicultura do eucalipto, tem-se o processo de arrendamento de propriedades privadas (MESQUITA et al., 2015). Esses processos, por sua vez, vêm transformando as relações de trabalho devido à especialização produtiva ocasionada pelas grandes empresas agrícolas e florestais.

\section{A INSERÇÃO DA SILVICULTURA DE EUCALIPTO NO MARANHÃO}

É inexata a data de inserção do eucalipto no Brasil, entretanto, há um consenso de que tenha ocorrido na segunda metade do século XIX - por volta de 1855 - no Rio Grande do Sul, com finalidade inicialmente decorativa e posteriormente sendo utilizado para a produção de postes, estacas, lenha e na própria construção civil. A evolução do cultivo dessa árvore no país avança à medida que o processo de industrialização do país cresce, já no início do século XX, mais especificamente o processo voltado para a produção de pasta de celulose para a fabricação de papel.

A primeira empresa a fabricar e usar celulose e papel de eucalipto foi a Gordinho, Braune \& Cia, em Jundiaí, por volta de 1927. Próximo a 1930, já se notavam modificações na paisagem agrícola da região, onde os eucaliptos eram facilmente notados. Em 1956, a Suzano Papel e Celulose inicia em Suzano a produção de celulose a partir da fibra de eucalipto, o que revolucionou a indústria de celulose no Brasil. Em 1960, a fábrica 
| Expansão da silvicultura do eucalipto e transformações no uso da terra em municípios do Oeste Maranhense |

|Allison Bezerra Oliveira | Diego Armando Souza Paz | Keilha Correia da Silveira |

Champion Papel e Celulose foi instalada em Mogi Guaçu, também em São Paulo (FOELKEL, 2005).

A partir de 1960, por meio da Lei no 5.106 , de 2 de setembro de 1966, houve um período de incentivos fiscais concedidos para o reflorestamento dessa monocultura, gerando um aumento da área de plantio de 500 mil para 3 milhões de hectares, iniciando, assim, o cultivo do eucalipto em escala econômica (SUZIGAN, 2000).

Nessa fase, houve o aumento de atividades empresariais na silvicultura, aumento da quantidade de funcionários vinculados a esse setor e expansão das áreas florestadas. Com a criação do Programa de Incentivos Fiscais ao Florestamento e Reflorestamento (PIFFR), houve uma grande expansão da silvicultura de eucalipto no país. Outros motivos também foram importantes para esse avanço, como programas públicos federais e estaduais, a exemplo do Programa de Reflorestamento de Pequenos e Médios Imóveis Rurais (Repemir); Programa Nacional de Papel e Celulose; Programa de Siderurgia a Carvão Vegetal; e Programa de Substituição Energética (ANTONANGELO; BACHA, 1998; BACHA, 1993).

A expansão da silvicultura do eucalipto por meio desses programas no sul do país gerou poucos empregos. Isso por conta da flexibilização e mecanização no processo produtivo, que também contribuiu para o aumento das concentrações de terras, além de transformações rápidas e expressivas na paisagem natural não só no sul, mas em todas as regiões que implantaram essa atividade em larga escala no Brasil.

No Maranhão, a inserção do eucalipto está diretamente vinculada ao Projeto Grande Carajás, implantado no estado do Pará no início da década de 1980. Esse grande projeto minerador veio com a criação da Estrada de Ferro Carajás (EFC), que liga a cidade de Parauapebas, no Pará, ao Porto do Itaqui, na capital maranhense São Luís. Isso porque o projeto minerador e sua estrada de ferro constituíram verdadeiro corredor de transporte entre os estados do Pará e Maranhão, o que permitiu a criação de projetos voltados para a produção de ferro-gusa no município maranhense de Açailândia.

Desta forma, o complexo siderúrgico iniciou, conjuntamente com a então Companhia Vale do Rio Doce (CVRD), a construção de área plantada de eucalipto para alimentar os fornos industriais. As áreas plantadas se expandiram nas duas décadas seguintes e permitiram à CVRD (detentora de grande parte delas) a tentativa de produção de pasta de celulose, através da Companhia de Celulose do Maranhão (Celmar), em 1992.

Havia ainda nesta ocasião, uma concentração de eucalipto apenas no município de Açailândia que conjuntamente com as plantações do estado do Pará permitiam a produção de combustível necessário para as caldeiras. Nos municípios de Imperatriz, São Pedro da 
| Expansão da silvicultura do eucalipto e transformações no uso da terra em municípios do Oeste Maranhense |

|Allison Bezerra Oliveira | Diego Armando Souza Paz | Keilha Correia da Silveira |

Agua Branca e Vila Nova dos Martírios (figura 2) não haviam ainda uma base plantada, permanecendo uma confluência entre cobertura vegetal nativa e aquela oriunda das atividades econômicas, em especial a pecuária (IBGE, 1997; ZEE/IMESC, 2010).

Figura 2 - Cobertura Vegetal nos municípios de Imperatriz, Cidelândia, Vila Nova dos Martírios e São Pedro da Água Branca (1992)

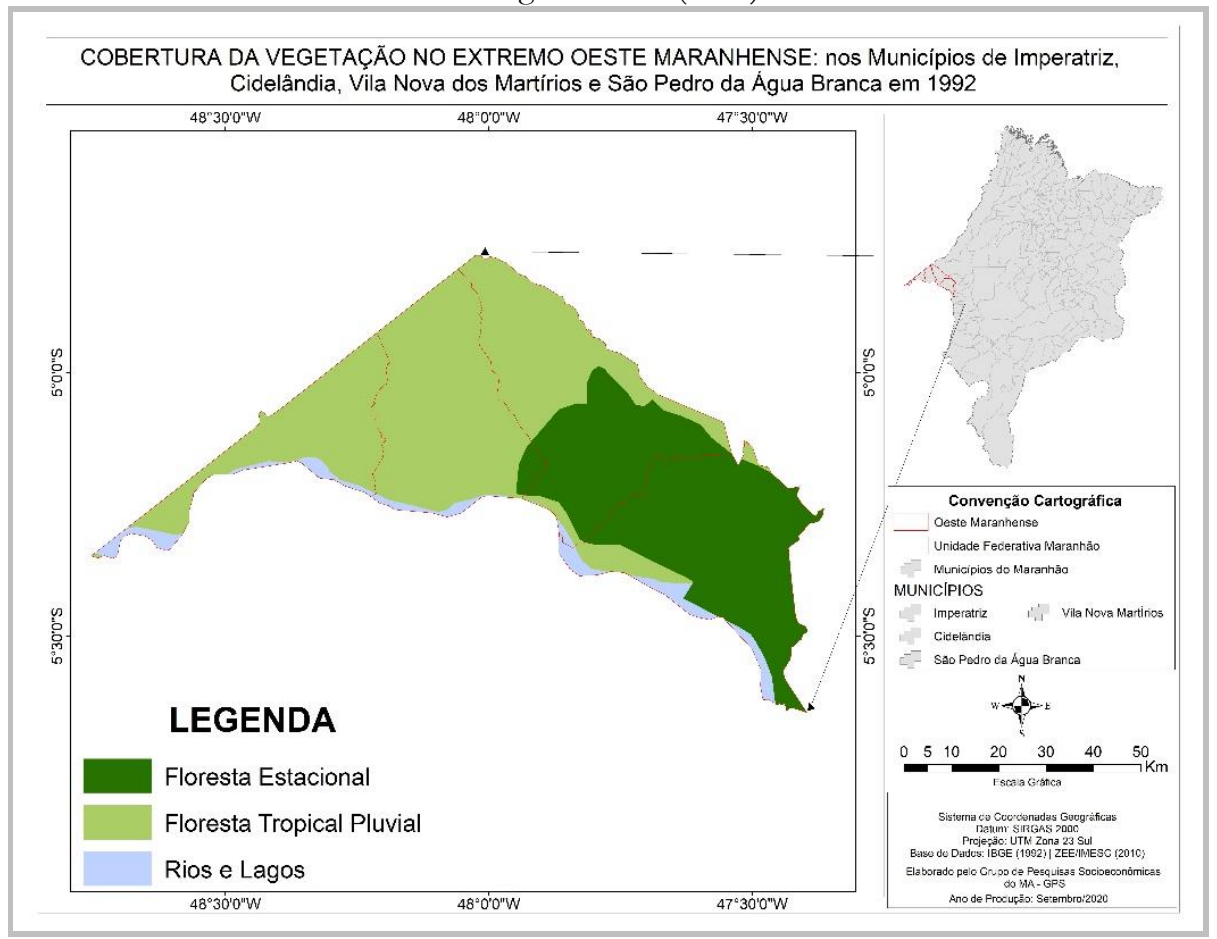

Fonte: os autores (2020) com base no IBGE (1992) e ZEE/IMESC (2010).

As áreas plantadas, além de extensa demarcação de terras que eram voltadas para a criação de animais, favoreceram a especulação fundiária desencadeada pela Cemlar, que proporcionou, principalmente na década de 1990 uma elevação no preço das terras na região. Neste contexto, a Celmar foi constituída por sociedade do grupo Risipar, da CVRD e da empresa japonesa Nisso Iwai Corporation. Posteriormente, a CVRD tornou-se sócia majoritária do projeto, que previa mais de um bilhão de dólares em reflorestamento de eucalipto entre 1992 e 1999. Para a Celmar executar esse empreendimento, ela passou a comprar áreas de diversos tamanhos, utilizando-se de variados recursos e pressões para conseguir as aquisições necessárias (FRANKLIN, 2008; MATIAS, 1994).

Contudo, com a privatização da CVRD e a dificuldade de liberação de todos os fundos necessários para a instalação industrial, o projeto foi interrompido e as áreas plantadas continuaram a atender a produção de lenha para a fabricação de carvão e um pequeno percentual voltado para a construção civil.

Para Matias (1994), os impactos de empreendimentos focados na silvicultura de eucalipto na região amazônica do Maranhão, especificamente se tratando do projeto 
| Expansão da silvicultura do eucalipto e transformações no uso da terra em municípios do Oeste Maranhense |

|Allison Bezerra Oliveira | Diego Armando Souza Paz | Keilha Correia da Silveira |

Celmar, seriam devastadores tanto no âmbito ambiental como social, uma vez que sua instalação intensificaria o processo de concentração de terras e, como consequência, de transformações na agricultura local, principalmente a de subsistência.

Com a privatização da CVRD e a dificuldade de liberação de fundos de investimentos do BNDES para a construção da planta industrial, o projeto Celmar foi engavetado, mas grande percentual de área plantada de eucalipto já havia sido incorporado a ele. Como consequência, em 2001 se iniciou o processo de desinvestimento e alienação da CVRD no setor de papel e celulose, e o destino da floresta de eucalipto passou a ser produzir carvão vegetal para abastecimento das usinas siderúrgicas de Açailândia (FRANKLIN, 2008).

Esse processo, além de contribuir para a desestruturação da agricultura familiar regional, através da grilagem de terras, valorização e especulação fundiária por grandes empresas de base agropecuária, acentuou o a exploração de madeira para a produção de carvão vegetal. O Gráfico 1 demonstra a série histórica da produção de carvão vegetal, lenha e madeira em toras no Maranhão, onde se insere o eucalipto.

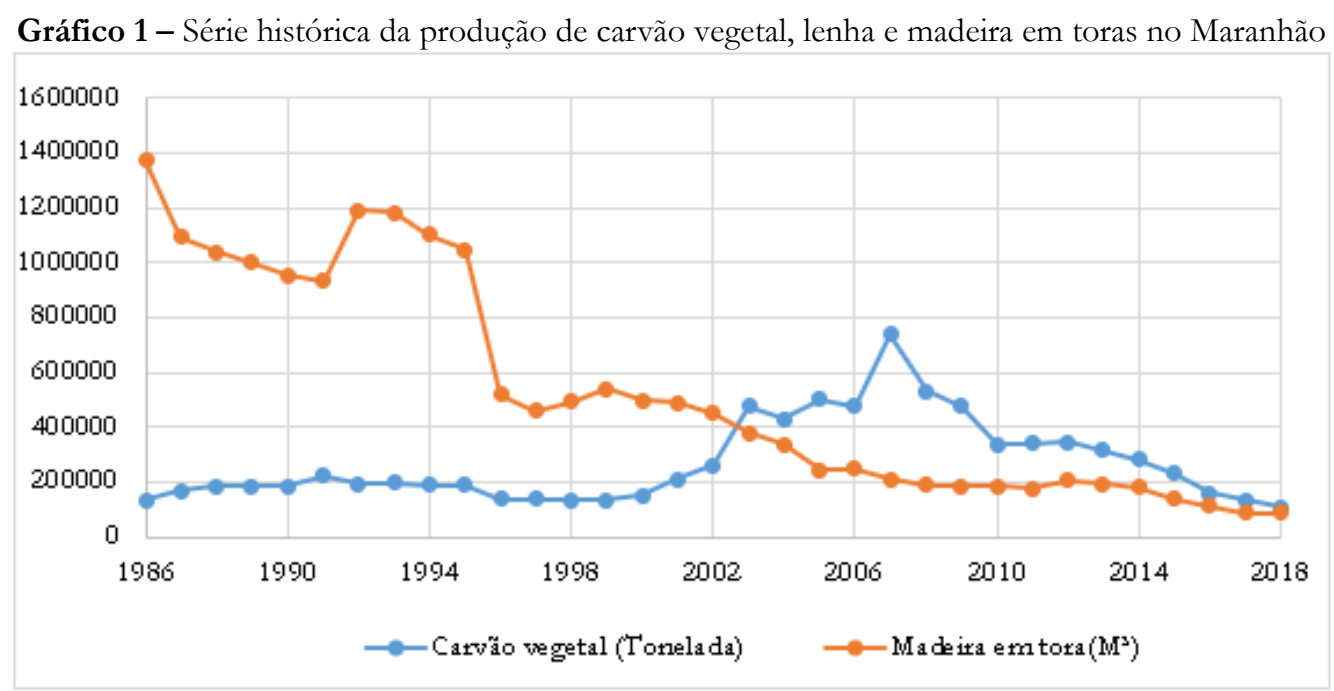

Fonte: IBGE (2019a), organizado pelos autores (2019).

Desta forma, conforme expresso no gráfico, observa-se que há uma produção considerável de carvão vegetal no Maranhão desde a implantação do complexo produtor de ferro-gusa, principalmente entre 1990 e 2000. Com processos de diminuição da produção em face da concorrência internacional, o que ocasionou o enfraquecimento do setor e o fechamento de três das cinco produtoras da cidade de Açailândia, o volume de produção diminuiu consideravelmente a partir do ano de 2010.

Esse percentual se acentua quando, ainda no ano de 2013, a Suzano Papel e Celulose começa as suas primeiras produções de pasta de celulose, resultado de grande 
|Expansão da silvicultura do eucalipto e transformações no uso da terra em municípios do Oeste Maranhense |

|Allison Bezerra Oliveira | Diego Armando Souza Paz | Keilha Correia da Silveira | incorporação tanto através da compra quanto do arrendamento de fazendas já existentes e de novas terras para o plantio de eucalipto. Tal empreendimento reestrutura e moderniza os impactos socioambientais esperados pelo projeto Celmar, na década de 1990.

\section{GRANDE PROJETO SUZANO PAPEL E CELULOSE E O AVANÇO DA SILVICULTURA DO EUCALIPTO}

Como é característico de empreendimentos desta natureza, antes mesmo da implantação da fábrica, iniciaram-se os processos de compra de terras nos municípios em questão, o que rapidamente provocou mudanças na cobertura vegetal, acentuando rapidamente o número de áreas destinadas à silvicultura do eucalipto (Figura 3).

Figura 3 - Cobertura Vegetal nos municípios de Imperatriz, Cidelândia, Vila Nova dos Martírios e São Pedro da Água Branca (1992)

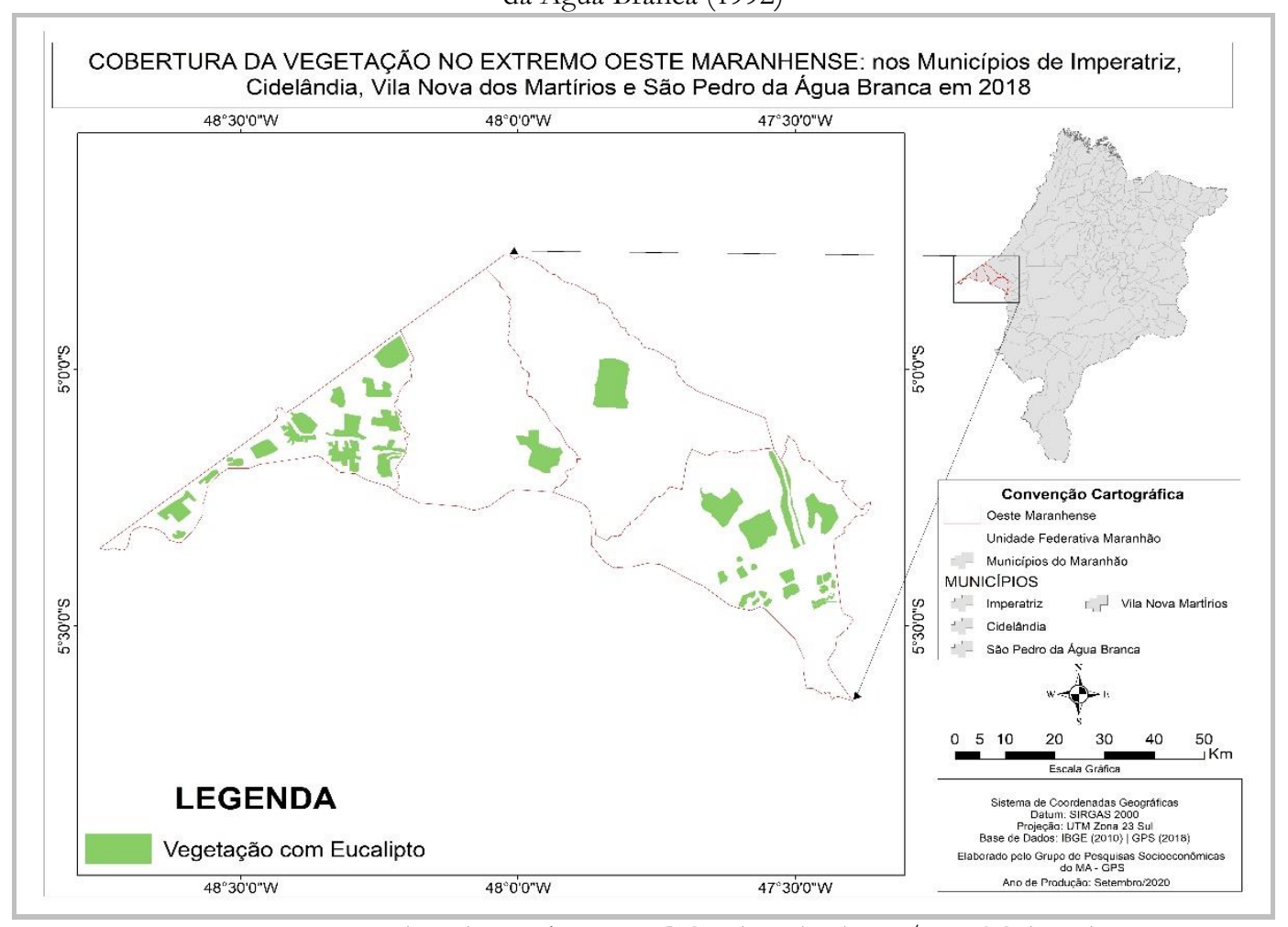

Fonte: os autores (2020) com base no IBGE (1992) e ZEE/IMESC (2010).

A base florestal constituída através da especulação gerada pela construção da Celmar juntou-se a outras áreas plantadas da CVRD, terras de produtores autônomos e novas áreas compradas e arrendadas para formar uma base produtora de matéria-prima. E foi essa base que permitiu o processo de implantação do Grande Projeto Suzano Papel e Celulose no município de Imperatriz, no ano de 2008.

Assim como é natural em empreendimentos desta natureza, e assim como ocorreu no passado com a Celmar, antes mesmo da instalação fabril já se iniciou o rápido processo 
| Expansão da silvicultura do eucalipto e transformações no uso da terra em municípios do Oeste Maranhense |

|Allison Bezerra Oliveira | Diego Armando Souza Paz | Keilha Correia da Silveira |

de compra de terras para o plantio do eucalipto, o que intensificou transformações na cobertura vegetal em muitos pontos nos municípios.

Mais do que a intensificação do eucalipto nos municípios estudados, a localização da fábrica representa, para além do acesso a infraestrutura, serviços e incentivos fiscais, um processo mais amplo de territorialização da produção fabril. Tal processo traduz-se em ampla aquisição de terras para a produção intensa e ininterrupta de matéria-prima que se estende por parte expressiva da Amazônia maranhense, mais precisamente no extremo oeste em sua faixa de fronteira com o estado do Pará e Tocantins (Figura 4).

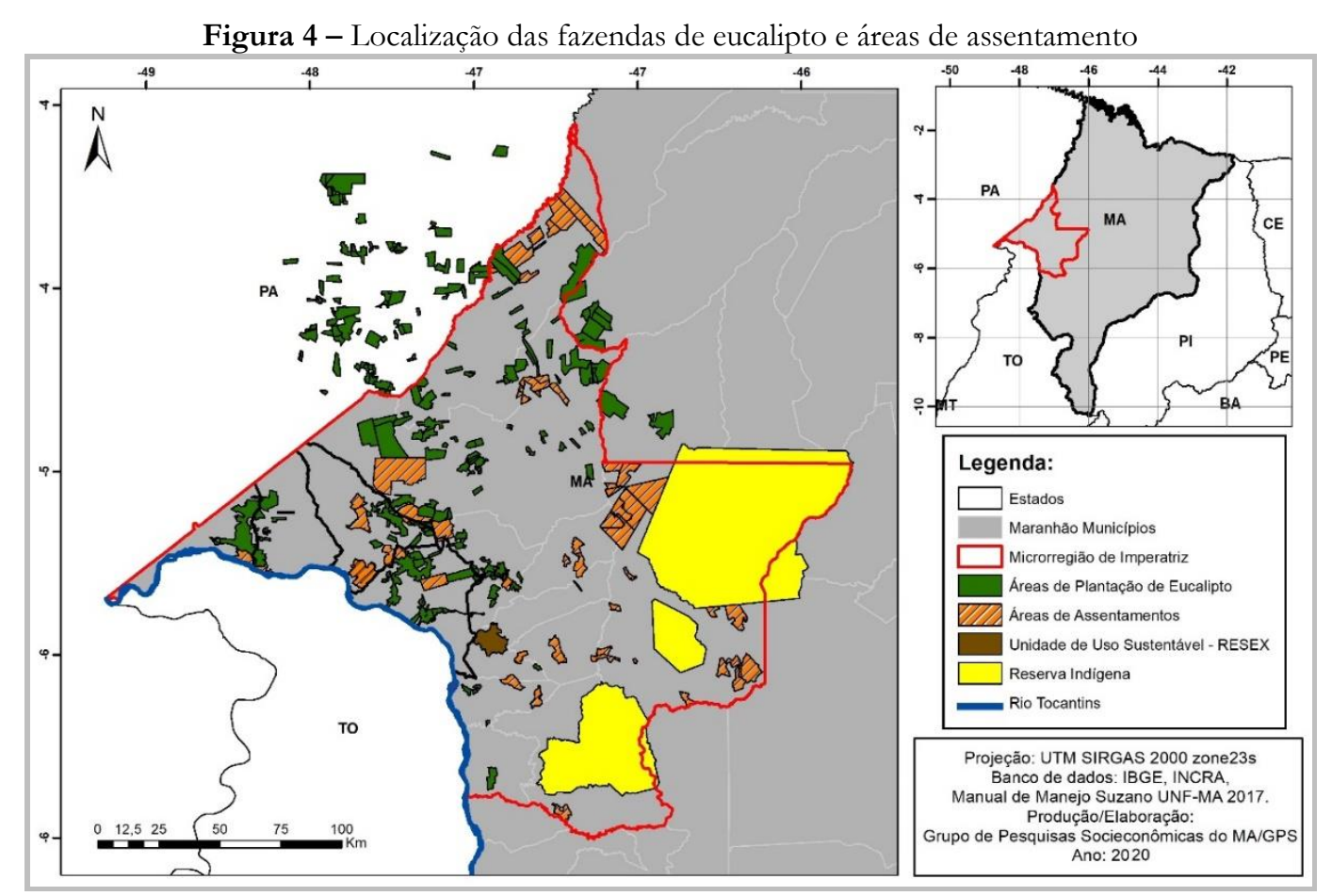

Fonte: Grupo de Pesquisas Socioeconômicas do MA - GPS (2019).

Para além de áreas historicamente destinadas à agropecuária, o eucalipto tem avançado no limiar de fronteiras com áreas de assentamentos, unidades de conservação de uso sustentável, e até sobre áreas de reservas indígenas. Esse avanço reitera movimentos ocorridos no passado, como aqueles oriundos da CVRD e o projeto Celmar e se intensifica, sobretudo, a partir do ano de 2005 (Gráfico 2). 
|Expansão da silvicultura do eucalipto e transformações no uso da terra em municípios do Oeste Maranhense |

|Allison Bezerra Oliveira | Diego Armando Souza Paz | Keilha Correia da Silveira |

Gráfico 2 - Evolução de áreas destinadas ao plantio de eucalipto no Maranhão (2005-2019)

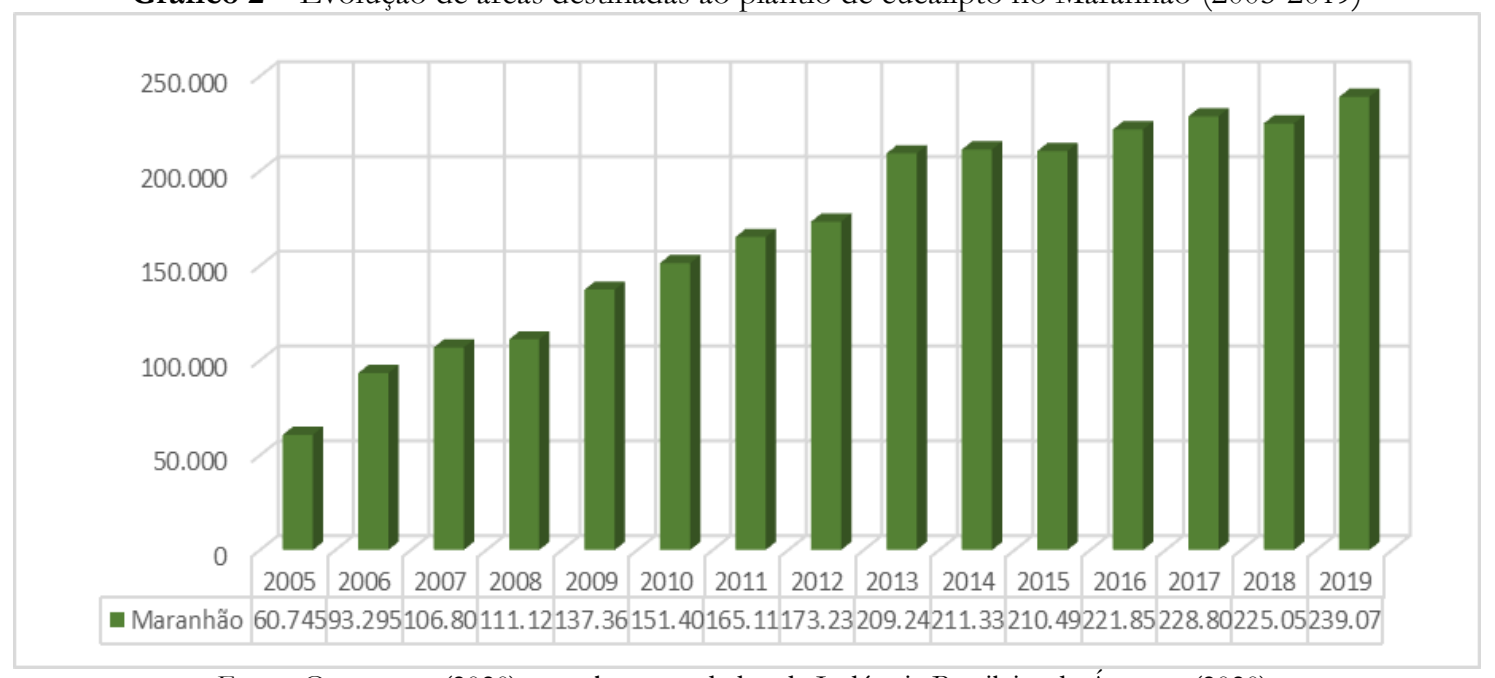

Fonte: Os autores (2020), com base em dados da Indústria Brasileira de Árvores (2020).

Em 2005, a base plantada resultante da Celmar e da cadeia siderúrgica de Açailândia era de 60.74 mil hectares que aumentam para 111.120 mil hectares em 2008 (ano do início das obras de construção fabril), chegando a 239.078 mil hectares plantados no ano de 2019, aumento de 398\% da área inicial no intervalo apresentado.

Fazendo este comparativo de evolução por município estudado (Gráfico 3), temos Imperatriz com 7.438 hectares de área plantada em 2018, representando aproximadamente 5,5\% do território municipal destinado a cultura. A área plantada em Cidelândia aumenta de 1.612 (2014) para 4.520 (2018) hectares com aumento de pouco mais de 3\% no período, e de São Pedro da Água Branca 1.023 (2014) para 12.428 (2018) hectares plantados de eucalipto, representando expansão de mais de $17 \%$ entre os anos destacados. O único município que apresenta redução da área plantada, o que pode ser resultado de algum processo de reestruturação das fazendas ou período de entre safra, é Vila Nova dos Martírios, que cai de 12.594 para 2.068 hectares. 
|Expansão da silvicultura do eucalipto e transformações no uso da terra em municípios do Oeste Maranhense |

|Allison Bezerra Oliveira | Diego Armando Souza Paz | Keilha Correia da Silveira |

Gráfico 3 - Percentuais de áreas plantadas de eucalipto em relação à área territorial municipal (hectares)

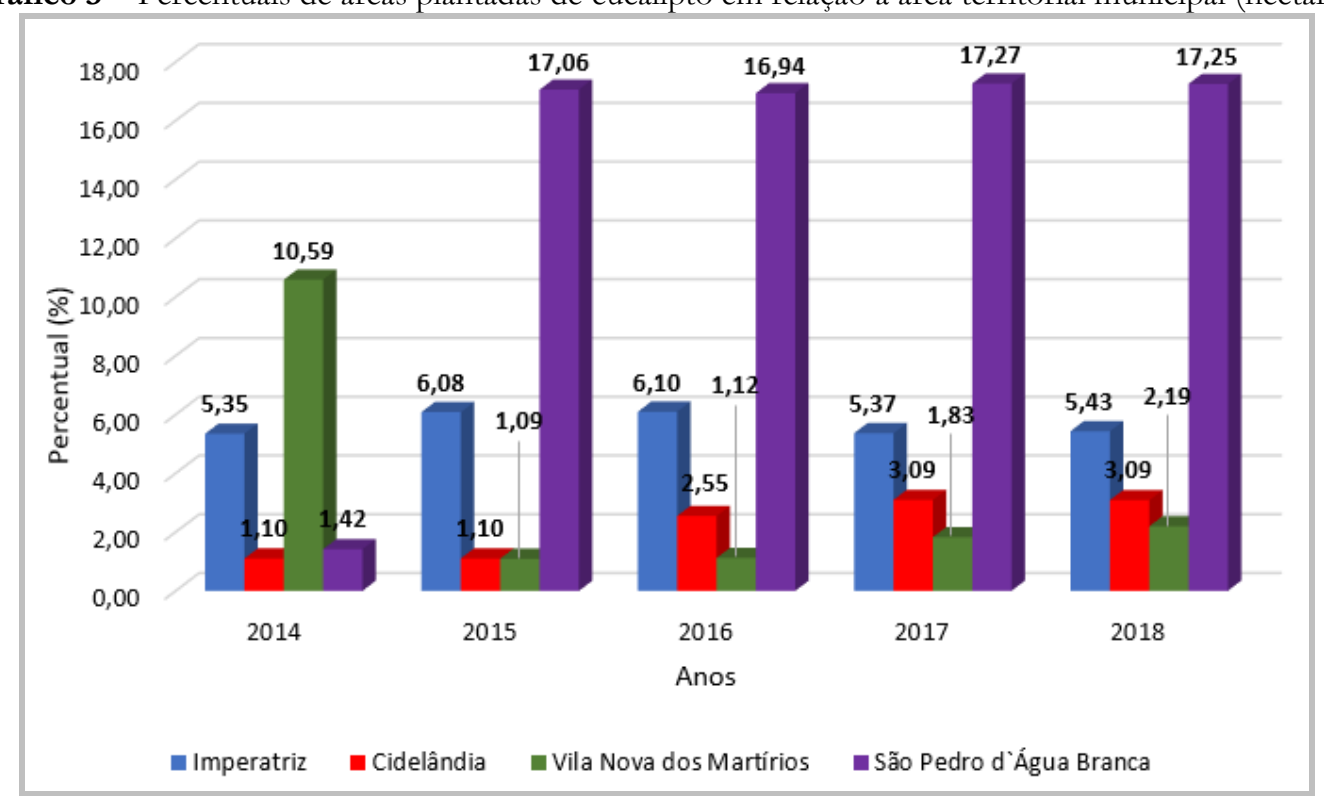

Fonte: Organizado pelos autores (2019), a partir de dados do IBGE (2019a).

Acerca desse tipo de avanço de terras, uma face da fronteira agrícola contemporânea, Sicsú e Lima (2000) afirmam que esse processo provoca uma mudança de valores em relação à terra: o valor de uso se converte em valor de troca. Isso impulsiona o absenteísmo rural e o arrendamento das terras, transformando agricultores em proprietários de plantações e modificando as formas de uso da terra e de apropriação do território.

Em especial, parte expressiva das áreas que hoje destinam-se ao eucalipto era anteriormente ocupadas pelas pequenas e médias propriedades destinadas à agricultura (principalmente a de subsistência) e pecuária. Boa parte da produção era destinada a feiras da região, principalmente de Imperatriz, segunda maior cidade do estado.

A possibilidade de venda, arrendamento ou mesmo produção de eucalipto em regime de monopsônio com a Suzano tem acirrado a valorização da terra e a mudança de padrões de produção historicamente existentes na região. Parte expressiva de proprietários de terra veem, no arrendamento da terra por exemplo, possibilidade de retorno econômico sem a necessidade de grandes investimentos. Outras áreas improdutivas são incorporadas ao manejo agroflorestal, obstaculizando o debate sobre reforma agrária além da intensificação do imaginário quanto a assentados serem obstáculos ao novo "progresso" no campo que se instala.

A tipificação do espaço rural por grandes propriedades de eucalipto é elemento central na materialização política da reestruturação produtiva da terra pelo agronegócio florestal e marca algumas das características das territorialidades dominantes na cadeia de 
| Expansão da silvicultura do eucalipto e transformações no uso da terra em municípios do Oeste Maranhense |

|Allison Bezerra Oliveira | Diego Armando Souza Paz | Keilha Correia da Silveira |

papel e celulose maranhense. O Quadro 1 apresenta algumas das principais fazendas ${ }^{1}$ incorporadas pelo grande projeto Suzano nos municípios em questão na última década, o que representa, apenas no quadro em destaque, o total de 94.215,35 hectares destinados exclusivamente à silvicultura do eucalipto.

Quadro 1 - Áreas ocupadas pelas fazendas de eucalipto da microrregião de Imperatriz

\begin{tabular}{|c|c|c|c|}
\hline Cidek̂ndia & Área (hectare) & Imperatrix & Área (hectare) \\
\hline Bloco Itabaiana- B & 882,0404397 & Sertaneja & 469,5616867 \\
\hline $\begin{array}{l}\text { Bloco Boa Esperança- } \\
\text { A }\end{array}$ & 6443,688994 & Amaralina & 550,6726911 \\
\hline São Jose 3 - A & 99,26146076 & Bloco Eldorado & 12315,42577 \\
\hline São Paulo & 329,5965491 & Monte Alegre - B & 170,5692475 \\
\hline Monte Alegre - A & 1058,708129 & Serra Branca & 292,7881712 \\
\hline $\begin{array}{l}\text { Bloco Boa Esperança - } \\
\text { A }\end{array}$ & 6443,078587 & Santa Rosa & 1318,957508 \\
\hline Boa $\mathrm{Fe}$ & 980,3075701 & Cruzeiro & 745,6728935 \\
\hline Bloco Itabaiana-A & 1216,903288 & Ferrovia 1 & 835,8674082 \\
\hline Bloco Itabaiana-C & 50,70034445 & Ferrovia 2 & 108,7255819 \\
\hline Monte Alegre - A & 1058,70813 & Santa Maria & 3917,664422 \\
\hline São Jose $3-\mathrm{B}$ & 1127,072527 & São Joao & 671,4954084 \\
\hline Verão Vermelho & 612,560856 & Fabrica Imperatriz & 3887,47976 \\
\hline $\begin{array}{l}\text { Vila Nova dos } \\
\text { Martírios }\end{array}$ & Área (hectare) & $\begin{array}{c}\text { São Pedro D'Água } \\
\text { Branca }\end{array}$ & $\begin{array}{c}\text { Área } \\
\text { (hectare) }\end{array}$ \\
\hline Campo Alegre & 375,8644322 & \multirow{2}{*}{ Bloco Jurema } & \multirow{2}{*}{23133,39947} \\
\hline Pioneira & 678,7827403 & & \\
\hline São Lourenco & 147,7217687 & \multirow{2}{*}{ Franqueza } & \multirow{2}{*}{202,6581628} \\
\hline São Lucas & 524,2894247 & & \\
\hline Capixaba & 332,2342788 & \multirow{2}{*}{ Bloco Jurema } & \multirow{2}{*}{23133,11852} \\
\hline Boa Vista 3 & 99,76704932 & & \\
\hline
\end{tabular}

Fonte: Cadastro Nacional de Imóveis Rurais (INCRA, 2019).

Nesse sentido, a apropriação e o controle do território constituem elementos centrais para a reprodução do capital, uma vez que é no território que são delimitadas ações de exploração, produção e transformação de matérias-primas em mercadorias (Figura 5). O avanço de demarcações de áreas de plantio de eucalipto se configura na base material que fundamenta a invasão do capital hegemônico sobre áreas rurais em seus múltiplos contextos.

${ }^{1}$ Existe claro subdimensionamento de informações em relação ao quantitativo de fazendas e a extensão total de hectares. 
|Expansão da silvicultura do eucalipto e transformações no uso da terra em municípios do Oeste Maranhense |

|Allison Bezerra Oliveira | Diego Armando Souza Paz | Keilha Correia da Silveira |

Figura 5 - Demarcação política do território da silvicultura do eucalipto

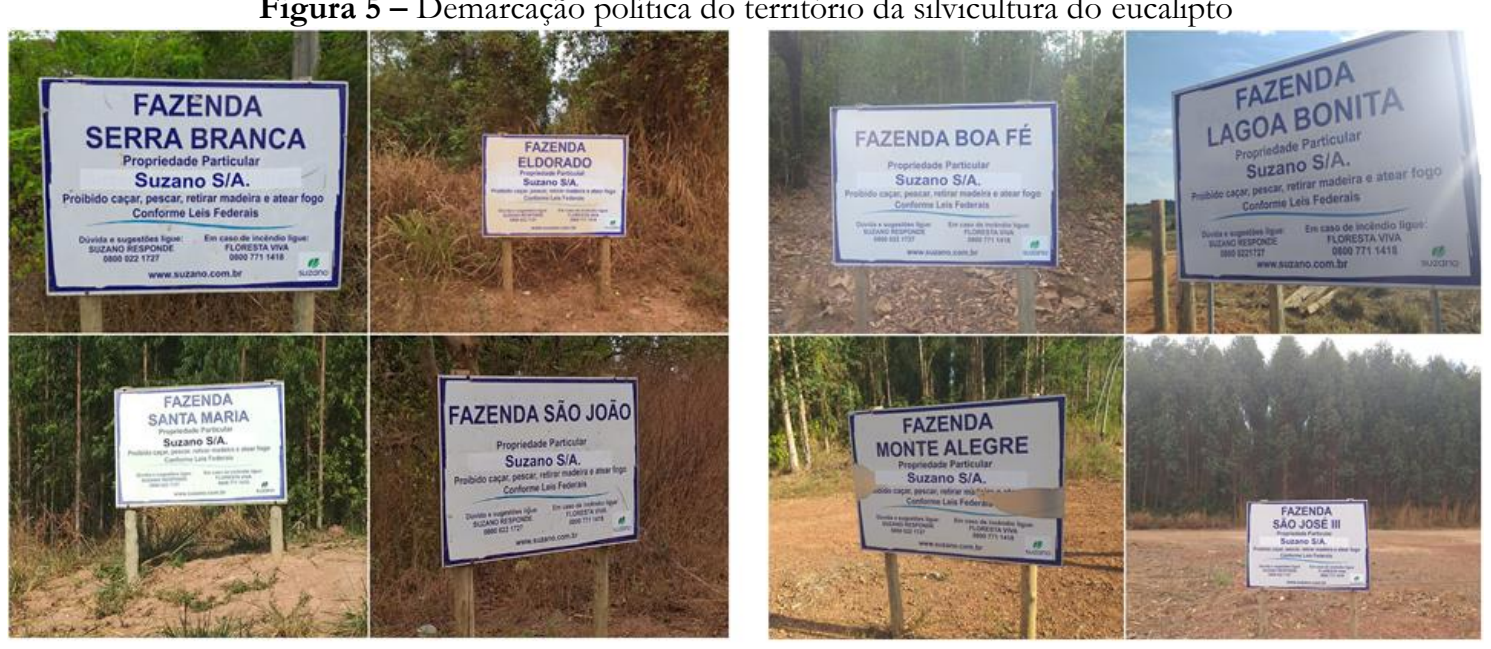

Fonte: Os autores (2020).

O movimento do avanço do eucalipto rege não apenas a reprodução do capital hegemônico sobre o uso da terra, mas representa também a reestruturação de atividades no campo sob uma lógica dominante que reorienta os sujeitos, os recursos, os objetos e ações sob uma ordem própria e destina desordem para os demais. No campo geográfico, o avanço dos emplacamentos, cercas, maquinários, funcionários são mais do que elementos de uma dinâmica econômica, eles podem ser também, sinônimos de conflitos, expulsão e centralização.

\section{O EUCALIPTO E TRANSFORMAÇÕES EM COMUNIDADES RURAIS}

Estas transformações apresentam resultados em escalas e formas diferentes no espaço rural. A pesquisa de campo sugeriu que, relações conflituosas com a Suzano são mais comuns com assentados do que com vilas rurais. Esta diferenciação pode ser percebida a partir de dois aspectos principais: moradores das vilas são menos críticos ao empreendimento e dependem menos do trabalho agrícola, uma vez que a força de trabalho das famílias não é focada apenas no plantio e criação de animais; as vilas também, ao contrário dos assentamentos, possuem em sua maioria a constituição definitiva da posse da terra.

No município de Imperatriz, destacam-se a Vila São Félix e o assentamento rural Eldorado. Na Vila são Félix, composta por 33 famílias, as relações com a empresa são mistas. Em entrevista com o diretor da associação de moradores, o mesmo informa que: "Tem uma conversa que os fazendeiros tem raiva da gente aqui por causa do arrendamento de terra pro eucalipto. Não tem emprego pra todo mundo, a Suzano não prometeu 
| Expansão da silvicultura do eucalipto e transformações no uso da terra em municípios do Oeste Maranhense |

|Allison Bezerra Oliveira | Diego Armando Souza Paz | Keilha Correia da Silveira | emprego pra todo mundo, os empregos melhores são para quem são qualificados. Aqui e acolá tem conflito com a Suzano por causa de uns problemas com poeira”.

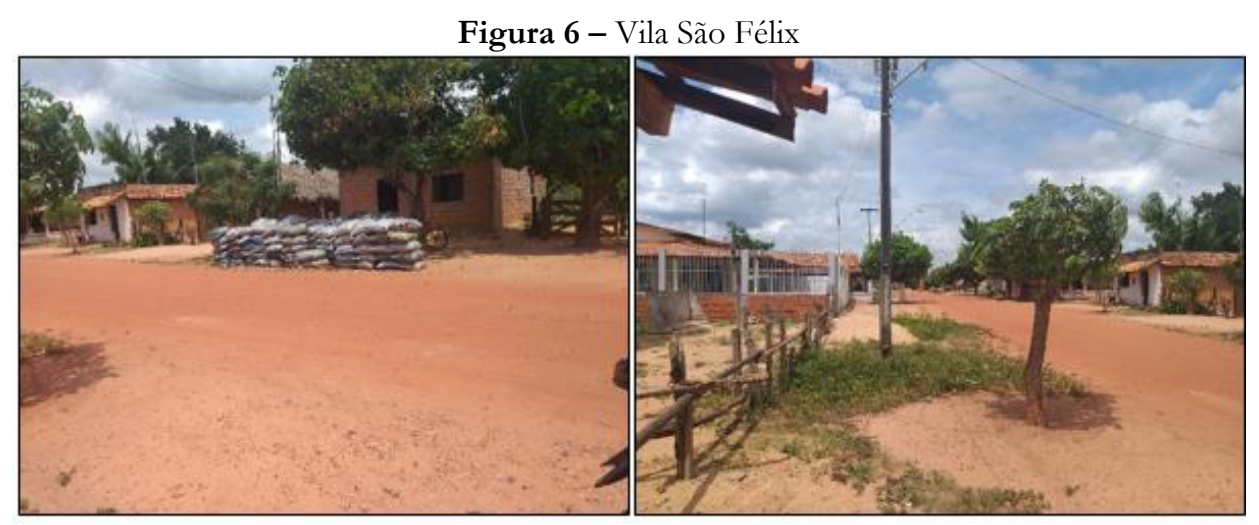

Fonte: Os autores (2020).

Quanto ao assentamento rural Eldorado (Figura 7), composto por cerca de 110 famílias, os assentados em entrevista destacam que, embora as relações com a Suzano, que é quem detém a posse das terras, sejam harmoniosas, a rápida expansão de áreas privadas da empresa e o consequente plantio do eucalipto limitam a capacidade produtiva das famílias a pequenas plantações de mandioca e milho, além da criação de pequenos animais no território de suas residências. Para eles, o avanço sobre áreas de coco-babaçu é preocupante já que o extrativismo vegetal é importante fonte de renda.

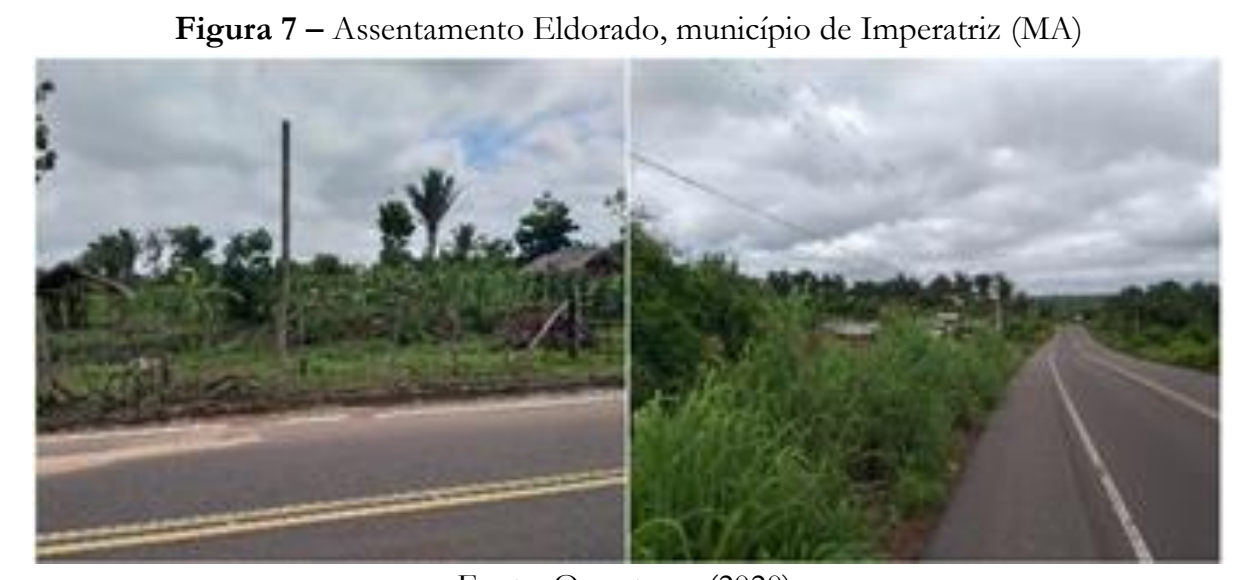

Fonte: Os autores (2020).

No povoado Trecho Seco em Cidelândia (Figura 8), moradores evidenciam que o número significativo de arrendamento de terras para o eucalipto diminuiu a porção de áreas destinadas à pecuária, o que elevou o preço da carne bovina. E que, "no começo (primeiras plantações) era bom para emprego porque o eucalipto era cortado no motor-serra e também tinha de ter uma segunda pessoa com machado para 'desengalhar', hoje uma máquina faz tudo sozinha. Não há emprego no eucalipto para nós”. A diminuição da 
| Expansão da silvicultura do eucalipto e transformações no uso da terra em municípios do Oeste Maranhense |

|Allison Bezerra Oliveira | Diego Armando Souza Paz | Keilha Correia da Silveira | criação bovina veio acompanhada da perda de empregos de trabalhadores rurais vinculados diretamente a esta atividade como caseiros, vaqueiros etc.

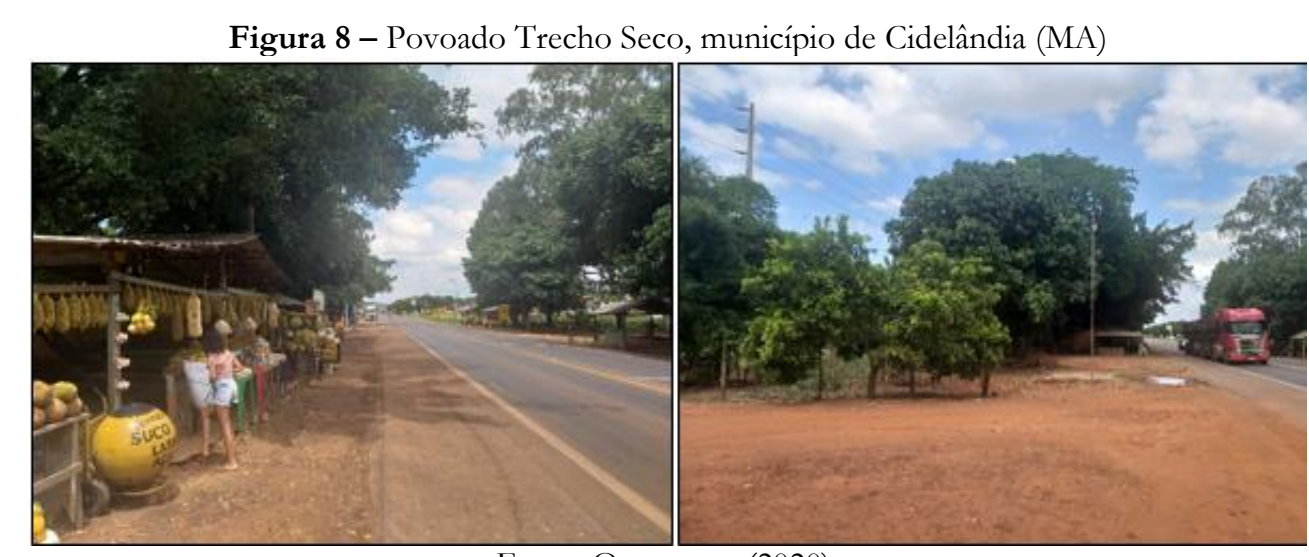

Fonte: Os autores (2020).

No município de Vila Nova dos Martírios, destaca-se o assentamento Sapucaia (Figura 9), existente desde 2002 e abriga com 150 famílias, que produzem arroz, mandioca, farinha, melancia, feijão, milho, abacaxi e também vivem da extração do coco-babaçu. Moradores em entrevista pontuaram aspectos semelhantes a outros municípios, como elevação do preço da carne em razão da diminuição de áreas destinadas à pecuária, e que, desde o grande projeto Ceumar, a relação com a silvicultura é conflituosa já que no passado áreas plantadas inteiras foram destruídas pelo projeto.

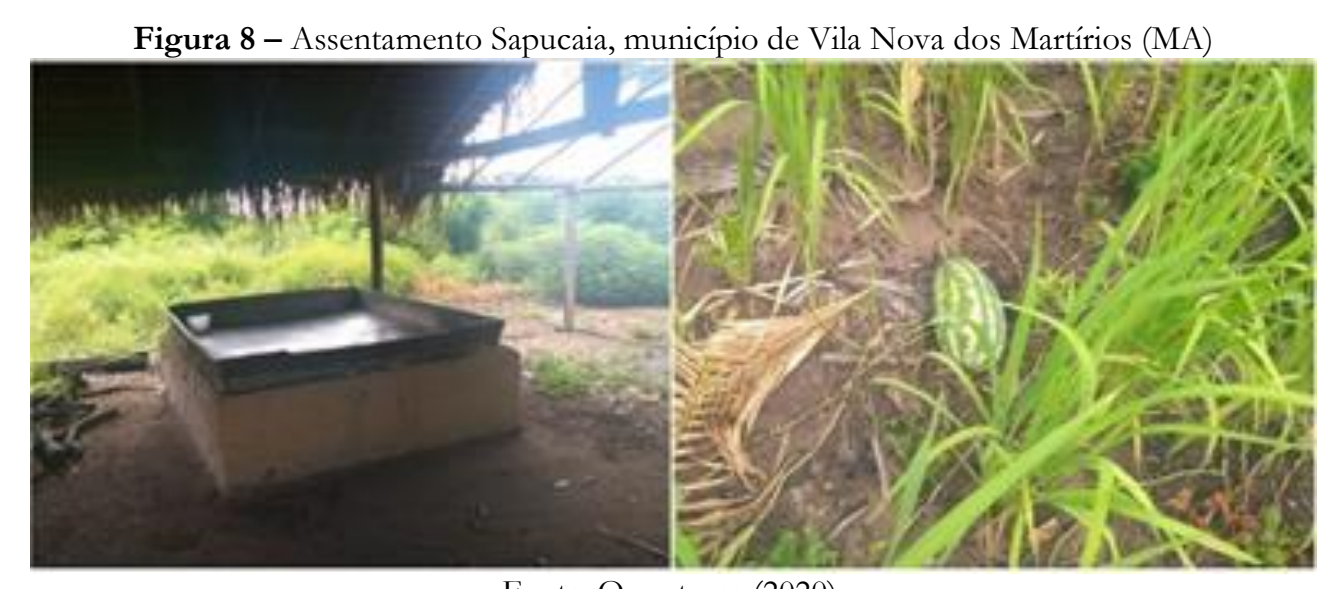

Fonte: Os autores (2020).

Frente ao grande projeto Suzano relatam: "O interesse da Suzano na terra (do assentamento e em volta dele) não é para plantar, visto que é "terra alagada", mas para transformar em reserva florestal. Nossa produção de frutas e legumes é mais barata para a população e, se diminuir, encarecerá o preço a todos. No início, a Suzano ofertava alguns empregos, mas agora é tudo feito pelas máquinas". 
| Expansão da silvicultura do eucalipto e transformações no uso da terra em municípios do Oeste Maranhense |

|Allison Bezerra Oliveira | Diego Armando Souza Paz | Keilha Correia da Silveira |

A mecanização da silvicultura está no cerne do agronegócio florestal e é elemento central na reestruturação pela qual essa cadeia produtiva passou nos últimos anos. Ela é fundamental para manter a produtividade nas economias de escala nas quais a exportação de pasta de celulose está inserida. Entretanto, no discurso de "emprego e renda" propagado pela empresa e representantes políticos, essa particularidade não é mencionada, o que desencadeia inicialmente a falsa sensação de emprego e renda para a população.

O assentamento Água Branca, em São Pedro da Água Branca, criado em 2006, possui atualmente 43 famílias. Uma das principais transformações apresentadas pelo presidente da associação de moradores é relativa aos venenos usados nas plantações de eucalipto, que escoam para o rio próximo à comunidade e afetam a produção do assentamento. "Apesar deles comunicarem que irão jogar o veneno, esse veneno escoa todo para nosso rio que utilizamos a água na nossa roça", explica.

Para alguns trabalhadores, a problemática em torno do veneno e da diminuição de áreas destinadas à agropecuária tem resultado na diminuição da produção de culturas como a mandioca, arroz e feijão, mas também de hortifrutigranjeiros. Em entrevista, funcionário de fazenda arrendada para a produção de eucalipto destaca que, boa parte das fazendas que hoje se dedicam a silvicultura, era anteriormente destinada à produção animal, como pecuária, ovinocultura e piscicultura, e que a pequena criação tem sofrido maior diminuição.

Estas modificações, por consequência, têm proporcionado outras transformações, sobretudo aquelas em torno de formas históricas de trabalho no campo, como nas palavras de um ex-agricultor empregado em uma fazenda de eucalipto: "antes se tinha mais trabalhadores que tomavam conta do gado, cabras, peixes e também de roçar, quando precisava, agora só tem eu. Já na área do eucalipto vem o pessoal deles”.

Embora os dados não possam associar de forma direta - e existe uma diversidade de aspectos que interfiram nestas questões, como crédito agrícola, êxodo rural, diminuição da capacidade produtiva das famílias, diminuição da propriedade da terra, grilagem, especulação fundiária etc. - é salutar destacar que, o aumento de áreas destinadas ao eucalipto, coincide com a diminuição da produção agrícola das quatro principais culturas agrícolas plantadas nos municípios: arroz, milho, feijão e mandioca (Gráfico 4), de acordo com os dados do IBGE (2019b). 
|Expansão da silvicultura do eucalipto e transformações no uso da terra em municípios do Oeste Maranhense |

|Allison Bezerra Oliveira | Diego Armando Souza Paz | Keilha Correia da Silveira |

Gráfico 4 - Percentual territorial de produção de arroz, feijão, mandioca e milho nos municípios de Imperatriz, Cidelândia, São Pedro d’agua Branca e Vila nova dos Martírios

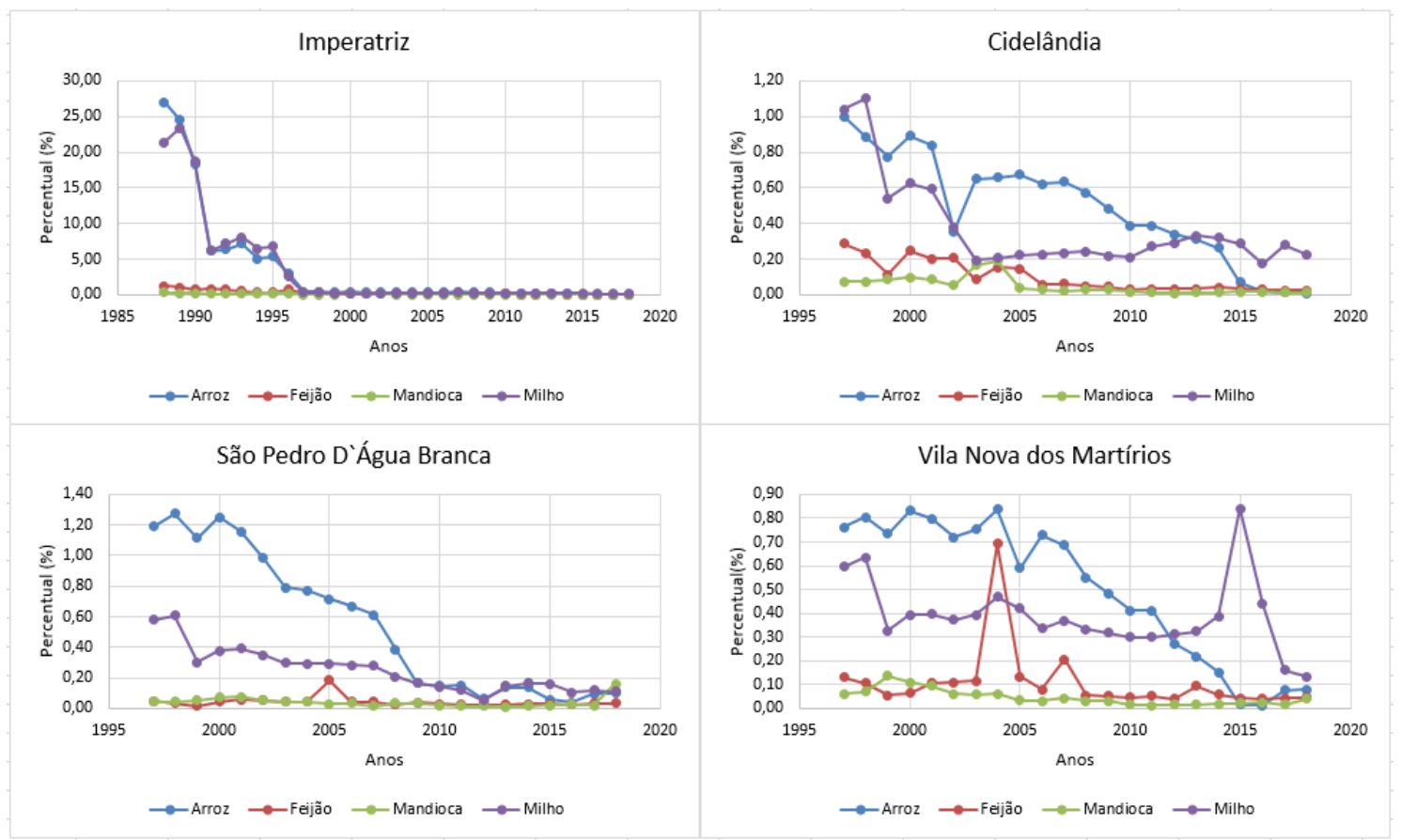

Fonte: Organizado pelos autores (2019), a partir de dados do IBGE (2019b).

Os gráficos apresentam o percentual em relação à extensão territorial dos municípios, de áreas em hectares destinadas ao plantio de arroz, feijão, mandioca e milho. Em todos os municípios, considerando a série histórica, há uma diminuição no quantitativo de hectares destinado para a produção. Embora outros elementos interfiram nestes aspectos, como já mencionado, como o próprio caso de Imperatriz em que o desmembramento de outras áreas para a constituição de novos municípios e a própria urbanização sejam elementos significativos, é salutar destacar que a partir da década de 1990 essa diminuição se intensifica.

Em termos quantitativos, a área total destinada as quatro culturas em Imperatriz em 1997 era 1250 hectares, reduzindo para 236 hectares em 2018. De forma semelhante, Cidelândia apresenta no ano de 1997 área total de 3513 hectares para as culturas destacadas, essa extensão cai para 397 hectares em 2018. São Pedro da Água Branca participa de processo semelhante, a área total para as culturas em 1997 era de 1072 hectares que foi reduzida para 291 hectares. E, por fim, Vila Nova dos Martírios onde a área total para as culturas foi reduzida de 1839 hectares em 1997 para 355 hectares em 2018.

\section{CONSIDERAÇÕES FINAIS}

Para além dos quatro municípios estudados em destaque, a expansão da silvicultura de eucalipto no Maranhão trata de projeto mais amplo de territorialização do grande capital 
| Expansão da silvicultura do eucalipto e transformações no uso da terra em municípios do Oeste Maranhense |

|Allison Bezerra Oliveira | Diego Armando Souza Paz | Keilha Correia da Silveira | agroindustrial no estado. Esse avanço consolida processos no passado de concentração de terra, expansão da fronteira agrícola, além de tecnicização do uso da terra com vistas à exportação, reestruturando enormes áreas que se expandem para outros territórios no Maranhão.

Neste contexto, foi observado número significativo de imóveis rurais destinados para a produção de eucalipto, adquiridos a partir da instalação da Suzano na região, boa parte deles, anteriormente destinados para a pecuária e a agricultura, que serve ao abastecimento local. Esse aumento tem se dado na última década sobretudo pela compra direta e pelo arrendamento, que se tornou opção econômica ao grande latifundiário.

A diminuição de forma geral no acesso à terra tem reduzido a capacidade produtiva de assentados e pequenas vilas rurais, que se veem cada vez mais cercados da monocultura e fluxo de caminhões. Embora os dados não possam associar diretamente ao eucalipto, é factível evidência que os dados e as fala dos entrevistados sugerem interferência dessa monocultura sobre áreas de plantio de culturas como arroz, mandioca, feijão e milho, principalmente a partir da década de 2000.

A mecanização da produção do eucalipto, característica do agronegócio florestal, é elemento pouco discutido com a população de áreas destinadas ao eucalipto, e essa estratégia insere na população rural a percepção de geração de emprego e renda. O que na prática é o contrário uma vez que postos tradicionais de trabalho como do caseiro, vaqueiro, diarista somem na medida em que formas históricas de uso da terra se modificam.

Por fim, o movimento do eucalipto sobre o oeste maranhense promove transformações no espaço rural não apenas sob o aspecto da modificação da cobertura vegetal, transformada em extensas áreas de monoculturas, mas, também, modifica aspectos tradicionais no campo. Modificação esta que não altera apenas alguma parcela de postos de trabalho, como vaqueiros, como também especula o valor da terra e dificulta processos de reforma agrária e transforma, muitas vezes, o pequeno produtor em um gargalo à compreensão do "progresso".

\section{AGRADECIMENTOS}

Este trabalho é resultado de pesquisa desenvolvida com auxílio financeiro concedido pela Fundação de Amparo à Pesquisa e ao Desenvolvimento Científico e Tecnológico do Maranhão (FAPEMA) sob a coordenação do Grupo de Pesquisas Socioeconômicas do MA - GPS/UEMASUL. 
| Expansão da silvicultura do eucalipto e transformações no uso da terra em municípios do Oeste Maranhense|

|Allison Bezerra Oliveira | Diego Armando Souza Paz | Keilha Correia da Silveira |

\section{REFERÊNCIAS}

ALMEIDA, J. G; MATTOS JUNIOR, J. S. A expansão do agronegócio no campo maranhense: racionalidades conflitantes e territórios em disputa. In: SANTOS, L. C. A.; SEABRA, G. F.; CASTRO, C. E. (Org.). Geografia: trabalho, sociedade e meio ambiente. São Luís: EDUEMA, 2018. p. 218-238.

ANTONANGELO, A.; BACHA, C. J. C. As fases da silvicultura no Brasil. Revista Brasileira de Economia, Rio de Janeiro, n. 52, v. 1, p. 207-238, jan./mar. 1998.

ARCANGELI, A. O mito da terra: uma análise da colonização da Pré-Amazônia Maranhense. São Luís: Editora Universitária da UFMA, 1987.

BACHA, C. J. C. A dinâmica do desmatamento e do reflorestamento no Brasil. 1993. Tese (Livre Docência) - Escola Superior de Agricultura Luiz de Queiroz, Universidade de São Paulo, Piracicaba, 1993.

BOLFE, E. L. [et al.]. Matopiba em crescimento agrícola: aspectos territoriais e socioeconômicos. Revista de Política Agrícola, Brasília, v. 25, n. 4, p. 38-62, out./dez. 2016.

FERREIRA, A. J. A. Políticas territoriais e a reorganização do espaço maranhense. 2008. Tese (Doutorado em Geografia) - Universidade de São Paulo, São Paulo, 2008.

FOELKEL, C. E. B. Eucalipto no Brasil, história de pioneirismo. Revista Visão Agrícola, Piracicaba, v. 1, n. 4, p. 66-69, jul./dez. 2005.

FRANKLIN, A. Apontamentos e fontes para a história econômica de Imperatriz. Imperatriz: Ética, 2008.

INDÚSTRIA BRASILEIRA DE ÁRVORES. Relatório de produção da silvicultura no Brasil. Brasília: IBÁ, 2020. Disponível em: <https://www.iba.org/>. Acesso em: 10 abr. 2020.

IBGE. Produção extrativista e da silvicultura no Brasil. Rio de Janeiro: IBGE, 2019a. Disponível em: < https://www.ibge.gov.br/>. Acesso em: 15 nov. 2019.

IBGE. Sistema IBGE de Recuperação Automática - SIDRA. Levantamento sistemático da produção agrícola 2008/2018. Rio de Janeiro: IBGE, 2019b. Disponível em: < https://sidra.ibge.gov.br/>. Acesso em: 1 nov. 2019.

Sistema IBGE de Recuperação Automática - SIDRA. Levantamento sistemático da cobertura vegetal do Maranhão 1992 - produção agrícola 2008/2018. Rio de Janeiro: IBGE, 2019b. Disponível em: <https://sidra.ibge.gov.br/>. Acesso em: 1 nov. 2019.

INSTITUTO MARANHENSE DE ESTUDOS SOCIOECONÔMICOS E CARTOGRÁfICOS. Zoneamento Ecológico Econômico. São Luís: IMESC, 2020. Disponível em: < http://www.zee.ma.gov.br/>. Acesso em: 30 set. 2020. 
|Expansão da silvicultura do eucalipto e transformações no uso da terra em municípios do Oeste Maranhense |

|Allison Bezerra Oliveira | Diego Armando Souza Paz | Keilha Correia da Silveira |

INSTITUTO NACIONAL DE COLONIZAÇÃO E REFORMA AGRÁRIA (Brasil). Cadastro Nacional de Imóveis Rurais. Brasília: INCRA, 2019. Disponível em: < https://cnir.serpro.gov.br/>. Acesso em: 20 mar. 2020.

MATIAS, M. A implantação da indústria de celulose no Maranhão: Celmar na Região Tocantina. Belém: Seminário Consulta Carajás, 1994. (Cartilha n. 3).

MESQUITA, B. A. [et al.]. Formação socioeconômica do estado do Maranhão. In: CASTRO, E. R.; CAMPOS, I. (Org.). Formação socioeconômica da Amazônia. Belém: NAEA/UFPA, 2015. p. 225-319.

OLIVEIRA, A. B. Indústria de celulose e o avanço da silvicultura do eucalipto na fronteira agrícola da Amazônia maranhense. Revista Geosul, Florianópolis, v. 34, n. 71, p. 301-327, abr. 2019.

OLIVEIRA, A. B; SILVA, D. L; LEAL, M. C. M. Indústria extrativista e mobilidade do capital e do trabalho na Amazônia Legal maranhense. Caderno de Geografia, v. 29, n. 2, 2019.

OLIVEIRA, D. M. V. [et al.]. Ocupação das terras do Maranhão ao longo do século XX e a injeção do grande capital internacional: "modernização" capitalista do campo e os conflitos agrários. In: ENCONTRO HUMANÍSTICO NACIONAL, 8., 2008, São Luís. Anais [...]. São Luís: Núcleo de Humanidades - NH/CCH/UFMA, 2008.

ROLIM FILHO, C. M. Formação econômica do Maranhão: de província próspera a estado mais pobre da federação. O que deu tão errado? 2016. Dissertação (Mestrado em Economia do Setor Público) - Universidade de Brasília, Brasília, 2016.

SICSÚ, A. B.; LIMA, J. P. R. Fronteiras agrícolas no Brasil: a lógica de sua ocupação recente. Nova Economia, Belo Horizonte, v. 10, n. 1, p. 109-138, jul. 2000.

SUZIGAN, W. Indústria brasileira: origem e desenvolvimento. São Paulo: Hucitec; Campinas: Editora da Unicamp, 2000.

VIEIRA FILHO, J. E. R. Expansão da fronteira agrícola no Brasil: desafios e perspectivas. Brasília: Rio de Janeiro: Ipea, 2016.

VIVEIROS, J. História do comércio do Maranhão. São Luís: Associação Comercial do Maranhão, 1954.

\section{Como citar este artigo:}

\section{ABNT}

OLIVEIRA, A. B.; PAZ, D. A. S.; SILVEIRA, K. C. da. Expansão da silvicultura do eucalipto e transformações no uso da terra em municípios do oeste maranhense. InterEspaço: Revista de Geografia e Interdisciplinaridade, v. 6, e202006, 2020. Disponível em: <http://dx.doi.org/10.18764/2446-6549.e202006>. Acesso em: 25 jan. 2020.

APA: 


\section{|Allison Bezerra Oliveira | Diego Armando Souza Paz | Keilha Correia da Silveira |}

Oliveira, A. B., Paz, D. A. S., \& Silveira, K. C. da. (2020). Expansão da silvicultura do eucalipto e transformações no uso da terra em municípios do oeste maranhense. InterEspaço: Revista de Geografia e Interdisciplinaridade, v. 6, e202006. Recuperado em 25 janeiro, 2020, de http://dx.doi.org/10.18764/2446-6549.e202006

\section{cc) commons}

This is an open access article under the CC BY Creative Commons 4.0 license.

Copyright (C) 2020, Universidade Federal do Maranhão.

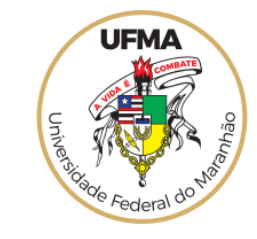

